\title{
Teaching NeuroImages: MRI findings in an infant with cavitating leukoencephalopathy
}

Annie Hong, MD, Peter Assaad, MD, and Shefali Karkare, MD

Neurology ${ }^{\circledR}$ 2019;92:e884-e885. doi:10.1212/WNL.0000000000006965

\author{
Correspondence \\ Dr. Hong \\ ahong2@northwell.edu
}

Figure MRI brain
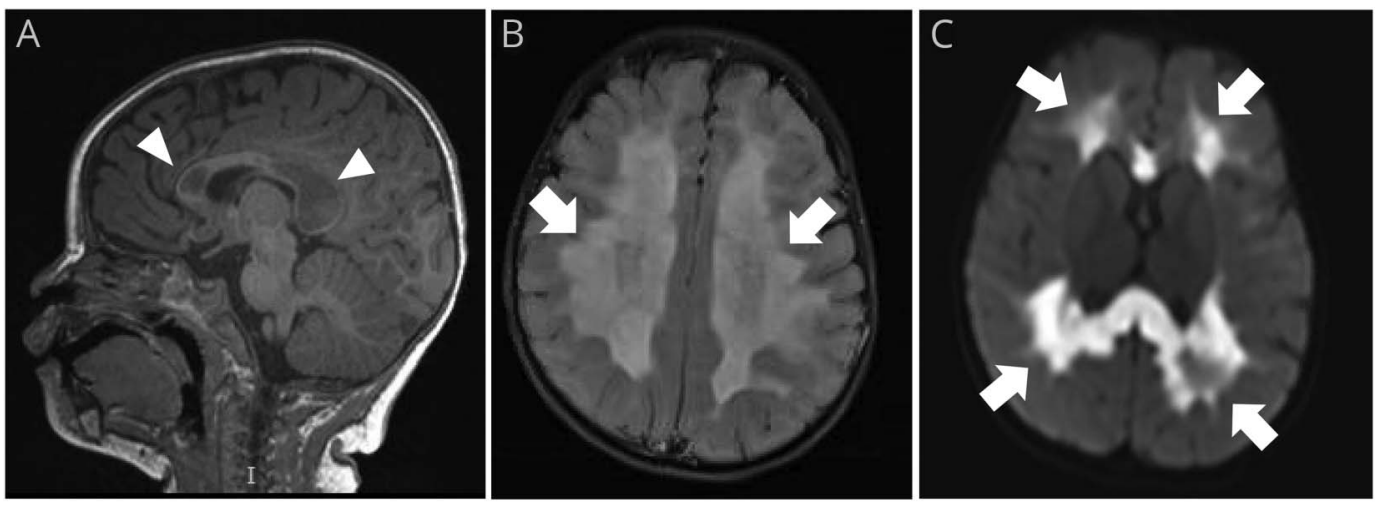

Sagittal T1-weighted image shows patchy leukoencephalopathy with cavitation affecting the corpus callosum and centrum semiovale, with relative sparing of underlying U-fibers and gray matter ( $\mathrm{A}$; arrowheads). Bilateral, symmetric $\mathrm{T} 2$ hyperintense white matter lesions on axial $\mathrm{T} 2$ fluid-attenuated inversion recovery did not enhance with contrast (B; arrows). Axial diffusion-weighted images demonstrate diffusion restriction ( $C$; arrows).

An 11-month-old previously healthy girl presented with irritability, weakness, and hypotonia following a febrile illness. Brain MRI revealed white matter signal abnormalities with diffusion restriction and cavitation of the corpus callosum (figure). Combined mitochondrial gene panel confirmed cavitating leukoencephalopathy secondary to a pathogenic variant, p.R386C, in the NDUFV1 gene, which encodes complex I. ${ }^{1}$ Cavitating leukoencephalopathy is a neurodegenerative disorder associated with genetic mutations of the mitochondrial complex proteins, characterized by acute neurologic deficits and progressive or intermittent clinical deterioration. Patients may have variable response to megavitamins, steroids, or IV immunoglobulin. ${ }^{2}$ She was treated with megavitamins and regained psychomotor milestones with no further events.

\section{Study funding}

No targeted funding reported.

\section{Appendix Authors}

\begin{tabular}{llll}
\hline Name & Location & Role & Contribution \\
\hline $\begin{array}{l}\text { Annie Hong, } \\
\text { MD }\end{array}$ & $\begin{array}{l}\text { Cohen Children's } \\
\text { Medical Center }\end{array}$ & $\begin{array}{l}\text { Corresponding } \\
\text { author }\end{array}$ & $\begin{array}{l}\text { Designed and conceptualized study, analyzed } \\
\text { the data, drafted the } \\
\text { manuscript for intellectual content }\end{array}$ \\
\hline $\begin{array}{l}\text { Peter Assaad, } \\
\text { MD }\end{array}$ & $\begin{array}{l}\text { Long Island Jewish } \\
\text { Medical Center }\end{array}$ & Author & $\begin{array}{l}\text { Interpreted the data, revised the manuscript for } \\
\text { intellectual content }\end{array}$ \\
\hline $\begin{array}{l}\text { Shefali } \\
\text { Karkare, MD }\end{array}$ & $\begin{array}{l}\text { Cohen Children's } \\
\text { Medical Center }\end{array}$ & Author & $\begin{array}{l}\text { Interpreted the data, revised the manuscript for } \\
\text { intellectual content }\end{array}$ \\
\hline
\end{tabular}

\section{MORE ONLINE}

$\rightarrow$ Teaching slides

links.lww.com/WNL/

A819

From the Division of Child Neurology, Department of Pediatrics (A.H., S.K.), and Department of Radiology (P.A.), Cohen Children's Medical Center, New Hyde Park, NY. Go to Neurology.org/N for full disclosures. Funding information and disclosures deemed relevant by the authors, if any, are provided at the end of the article. 


\section{Disclosure}

The authors report no disclosures relevant to the manuscript. Go to Neurology.org/ $\mathrm{N}$ for full disclosures.

\section{References}

1. Zafeiriou DI, Rodenburg RJT, Scheffer H, et al. MR spectroscopy and serial magnetic resonance imaging in a patient with mitochondrial cystic leukoencephalopathy due to complex I deficiency and NDUFV1 mutations and mild clinical course. Neuropediatrics 2008;39:172-175.

2. Naidu S, Bibat G, Lin D, et al. Progressive cavitating leukoencephalopathy: a novel childhood disease. Ann Neurol 2005;58:929-938. 


\section{Neurology}

\section{Teaching NeuroImages: MRI findings in an infant with cavitating leukoencephalopathy Annie Hong, Peter Assaad and Shefali Karkare \\ Neurology 2019;92;e884-e885 \\ DOI 10.1212/WNL.0000000000006965}

This information is current as of February 18, 2019

\section{Updated Information \& Services}

References

Subspecialty Collections

Permissions \& Licensing

Reprints including high resolution figures, can be found at: http://n.neurology.org/content/92/8/e884.full

This article cites 2 articles, 0 of which you can access for free at: http://n.neurology.org/content/92/8/e884.full\#ref-list-1

This article, along with others on similar topics, appears in the following collection(s):

All Imaging

http://n.neurology.org/cgi/collection/all_imaging

All Pediatric

http://n.neurology.org/cgi/collection/all_pediatric

Mitochondrial disorders

http://n.neurology.org/cgi/collection/mitochondrial_disorders

Mitochondrial disorders; see Genetics/Mitochondrial disorders http://n.neurology.org/cgi/collection/mitochondrial_disorders_see_gen etics-mitochondrial_disorders

MRI

http://n.neurology.org/cgi/collection/mri

Information about reproducing this article in parts (figures,tables) or in its entirety can be found online at:

http://www.neurology.org/about/about_the_journal\#permissions

Information about ordering reprints can be found online:

http://n.neurology.org/subscribers/advertise

Neurology ${ }^{\circledR}$ is the official journal of the American Academy of Neurology. Published continuously since 1951, it is now a weekly with 48 issues per year. Copyright (O 2019 American Academy of Neurology. All rights reserved. Print ISSN: 0028-3878. Online ISSN: 1526-632X.

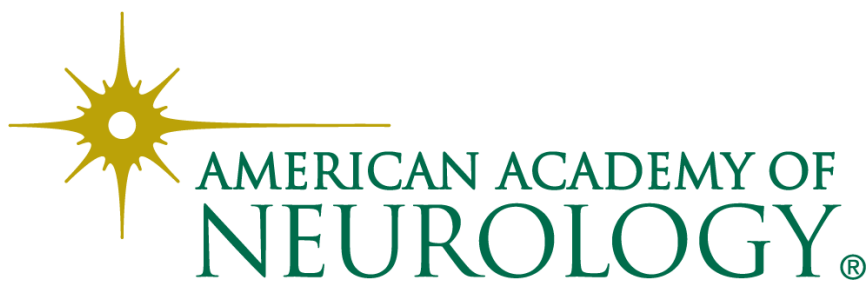

